\title{
THE EDUCATIONAL EVOLUTION IN IRAN AND GERMANY: THE CASE OF PRIMARY EDUCATION (GRUNDSCHULE)
}

\author{
ALI ASHRAFI \\ English Department, \\ University of Applied Science and Technology, \\ 10 Third Street, Tehran, Iran \\ E-mail: Ali.Ashrafi.Sarvak11@gmail.com \\ ORCID: https:/ / orcid.org/0000-0002-2427-6509
}

\begin{abstract}
Aim. In recent decades, according to the enormous transformation in educational systems, the importance of educational spaces in the developed world has been increasingly sought after by educators and due to think of all the more attractive these spaces, they have thought differently. The present study was conducted to study the evolution of the educational environment of primary schools in Iran and Germany and compare them with each other.

Methods. This research is descriptive research based on the comparative method. The study has also the standards criteria for designing primary schools in Iran and Germany.

Results. The results of the research point to various differences between schools in Iran and Germany and then justify the differences similarities between the organization of primary education, description of the primary education system, selecting and training teacher education and similarity how to select and educate the teacher.

Conclusion. The study showed In Iran, a major factor in the development of education is religion. In the pre-Islamic period, Zoroastrianism has been a factor in the philosophy and principles of education. After Islam, education has benefited from the philosophy and principles of Islam and has fully influenced primary education. But in the primary period of the German educational system, politics, ideology and the opinion of educators have played an important role in the transformation of education and, as such, in primary education.
\end{abstract}

Key words: Educational Evolution, Educational Spaces, Primary Schools, Iran, Germany.

\section{THE RESEARCH PROBLEM}

$\mathrm{N}$ owadays, the subject of how to manage education is very important. The education of each country is the main organization responsible for preserving and controlling values, education for the future generation of society and, ultimately, for the excellence of humans. This movement beginning from the primary school and in fact the foundation of humanization is introduced 
in this period. Also, the most important stage in all world education systems is the primary period because the personality formation and the individual's overall development in this period is more carried out during this period. Primary curriculum in different parts of the world is designed to raising children in physical, social, aesthetic, emotional, cognitive, moral and spiritual dimensions. The review of current experiences in the field of reforming the educational system of different countries shows that each One of them has principles for policy making and amending changes. The children of Third World countries are among the most deprived classes of society. Providing conditions for children to be free from any discrimination, their natural development is one of the important issues that has always attracted the attention of human societies as the advancement of human civilization has come to the fore.

The study of the evolution of Iranian education shows that one of the main goals of education in the past and present has provided the right to benefit from education. However, despite the many studies that public education officials have done over the recent years to generalize public education, for some reasons such as delaying the preparation of the program, lack of comprehensive and appropriate planning in this regard, lack of credits and qualifications in the provision of teachers and other educational facilities, a large group of young people, especially teenagers, have not yet been fully covered by public education.

On the other hand, the German education system was changed in 1949 by adopting the basic law of education, social, political and cultural foundations in Germany. The law explicitly emphasizes the right of all German children to have public education on their talents and abilities. Furthermore, the curriculum in Germany is decentralized and books are being compiled by other experts and endorsed by the Ministry of Education.

In general, the global goals of primary education are:

- Promoting students' emotional and social development and learning to recognize and manage emotions and how communicate with others.

- Enhance creative growth in students.

- Promoting cognitive development of students.

- Education of effective and informed citizens of individual and social rights and ultimately affecting sustainable development of society.

- Development of justice and equality in society.

- Education of powerful citizens for global communication.

In 2002, UNESCO identified two major challenges for elementary education: a severe teacher shortage and high levels of enrollment - Students in primary schools. The low budget allocated to primary school education, the lack of proper planning of the state for implementing the plan, Global education for primary school and the lack of public access to basic education for general education have been introduced as other major challenges (UNESCO, 2005) In the UNICEF (2019), the challenges of primary education including: Low quality education in some countries, lack of strategic plans in some countries to achieve the desired goals, the low level of education-specific priority in some 
countries, gender discrimination in educational systems in some countries (Wekesa, 2013).

However, the lack of adequate access to public education, low budget and low teachers' salaries, the lack of appropriate teacher training schemes and the lack of proper cooperation between countries in providing accurate information about their educational status appear to be among the main challenges of development Educational justice in the world is in the field of elementary school education.

The main purpose of this research is to achieve the weaknesses and strengths of our primary education in our country in comparison of Iran and the provision of solutions to improve these weaknesses and strengthening the strengths seems necessary.

\section{AIM AND RESEARCH QUESTIONS}

Primary education levels are called primary education, compulsory education, and public education. Nowadays, new research has shown that primary education plays an important role in the reduction of poverty and the realization of economic and social development programs. Therefore, the necessity of this research is to study the evolution of primary education and its influencing factors in Iran and Germany.

In Iran, it is referred to as the first stage of formal education and considered as the most popular stage. The period of this course in Iran is five years old and covers children in the first to fifth grades. In Germany, elementary education is provided at the undergraduate schools called Grundschule, and German children at the age of six enrolled in these schools and the length of their studies in these schools is 4 years (In the state of Berlin for 6 years).

Also, the primary organization and how to select the teacher education and primary curriculum will be examined. In this research, the research method is descriptive method. The results showed that in Iran, an important factor in the development of education is religion and religion. So that, in pre-Islamic era, Zoroastrianism has been considered a factor in the philosophy and principles of education. After Islam, education has benefited from Islamic philosophy and principles and has fully influenced education and elementary education. Until now, in Iran after the Islamic Revolution, Islamic values are also found in the philosophy of education and the religious beliefs of the elementary education period. But, in the primary period of the German education system, politics, ideology and ideas of educators have played an important role in the development of education and, as such, in primary education. As can be observed in the Wimar Republic, education was influenced by the political theories of democracy, and then, during the Nazis, was influenced by the ideology of Nazism and the superiority of the Nazi German race; during World War II and thereafter Was influenced by communist ideology and Marxist thoughts. In the new era, there have also been major reforms to eliminate the influence of these new educators' ideologies and educational ideas. 
In this research, the researcher tried to answer the following questions with regard to the education of elementary school in Germany:

- How is the development of primary education and its influential factors in Iran and Germany country?

- How is the organization of primary education in the country of Iran and Germany?

- What is the primary curriculum and how to implement it in the country of Iran and Germany?

- How is the selection, training and teacher training of teachers in Iran, Germany?

\section{THEORY}

In today's world, the issue of how to manage education is very important. The education of each country is the main organization responsible for the preservation and concentration of values, the education of the future generation of society and ultimately, excellence of human. Also, the most important stage in all worldwide education systems is the primary period because the personality and development of children is formed during this period more than any period. A review of current experiences shows that each country has adopted principles for policy making and reforming change.

For example, the German education system was changed in Germany in 1949 by adopting the basic law of education, social, political and cultural foundations in Germany. This law explicitly emphasizes the right of all German children to have public education on their talents and abilities (Beutner, Rasmus, 2017). The Islamic Republic of Iran is located in the northeastern hemisphere and in South Asia and the Middle East. Education and its evolution in Iran can be divided into three periods, the ancient era, the advent of Islam and contemporary times. The study of documents related to the history of education in Iran shows that for the first time on November 9, 1912. The Iranian education system includes children, primary schools, high schools, universities. In fact, the official education system of Iran actually emerged from the Constitutional Revolution and after the constitution and its amendment were introduced. Until the Constitutional Revolution, education continued in traditional school buildings and teachers were literally literate through religious centers and learning the jurisprudence and the principles and teachings of the Quran, and they learned what they knew in the traditional way of teaching children and adolescents. Usually, the government agencies did not have any supervision over them, and the lessons taught without a syllabus consist of reading, writing, calculating, Quran reading, and Arabic script (www.iranculture.org).

In 1847, Amir Kabir established the first modern institute in Iran. In the 1922, the Law on the Supreme Council of Culture was approved for the administration of all schools. There were two levels of elementary and secondary 